\title{
THE LATE ANTIQUE CHURCH OF SAINT LAWRENCE, BANJOL (ISLAND OF RAB, CROATIA) - RESULTS OF THE FIRST TWO ARCHAEOLOGICAL CAMPAIGNS (2015-2016)
}

\section{GIAN PIETRO BROGIOLO, ALEXANDRA CHAVARRÍA ARNAU, FEDERICO GIACOMELLO, MILJENKO JURKOVIĆ, GORAN BILOGRIVIĆ}

\author{
UDC: $726.54(497 \cdot 572) " 05 "$ \\ 902.2 \\ Preliminary communication \\ Manuscript received: 31. 03. 2017. \\ Revised manuscript accepted: 07. 04. 2017. \\ DOI: 10.1484/J.HAM.5.113754
}

G.P. Brogiolo*

A. Chavarría Arnau*

F. Giacomello*

M. Jurković**

G. Bilogrivićc*

Preliminary results of the first excavation campaigns at the site of Saint Lawrence in Banjol on the island of Rab are presented. These excavations revealed the remains of two consecutive churches, a large Late Antique and a smaller medieval one. An in situ grave and a secondary skeletal mass burial were also discovered. Finds of stone sculptural decoration belonging to the first church and contemporary metal finds from the mass burial are also discussed.

Keywords: Late Antiquity, church architecture, $\sigma^{\text {th }}$-century church sculpture, Saint Lawrence, Banjol, Rab, Corinth-type belt buckles, burials

The island of Rab, situated in the southern part of the Quarnero gulf, towards Dalmatia, has been in the focus of our joint interest since $2005 .{ }^{1}$ After having excavated a Roman villa in Kaštelina, ${ }^{2}$ and reviewed the layout of the Late Antique castrum in Barbat, ${ }^{3}$ a large field survey was initiated for a better understanding of the transformations of the historical landscape of the island. ${ }^{4}$

During this survey we have recognized the potential of the site of Saint Lawrence in Banjol, a place located $3.5 \mathrm{~km}$ south of the ancient urban centre of Rab (fig. 1-2). The site is located in a large agricultural area covering most of the central strip of the island, and dating at least from Roman times. Numerous Roman villas have been identified in this area. The old Austrian cadastre (fig. 3) refers to the area as Saint Lawrence and includes:

(a) an area overlooking a road and the sea, now occupied by a modern building, which, when constructed, lowered the ground level by $2 \mathrm{~m}$;

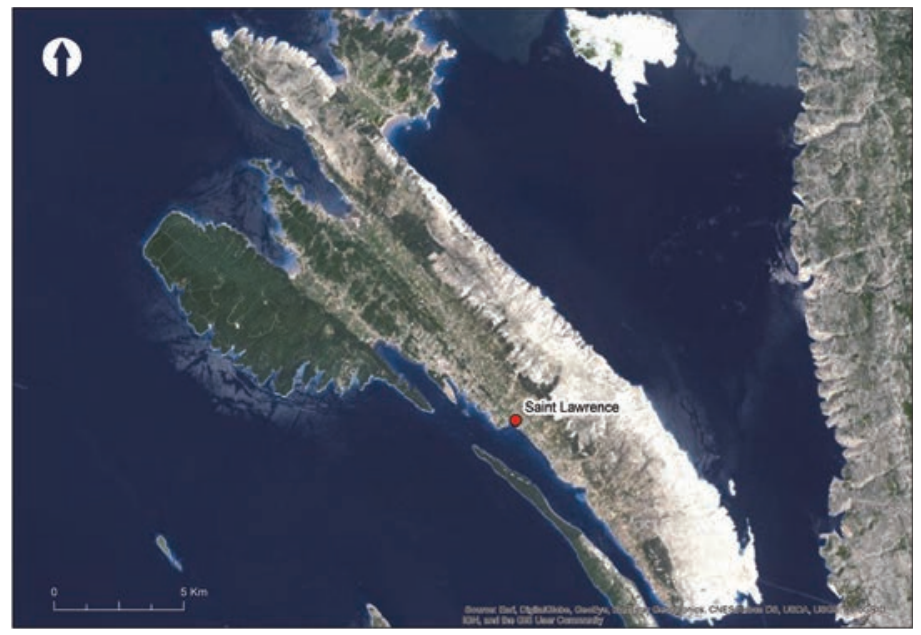

Fig. 1. Island of Rab and location of the site.

(b) a rectangular field of about $500 \mathrm{~m}^{2}, 5$ the subject of the archaeological excavation. It is delimited by two

\footnotetext{
* Università degli Studi di Padova, Dipartimento dei Beni Culturali.

** University of Zagreb, Faculty of Humanities and Social Sciences, Ivana Lučića 3, Zagreb

${ }^{1}$ The joint research program of Padova and Zagreb Universities, within the International research center for late antiquity and the middle ages, has started in 2005 through a larger INTERREG project of Padova University, with the excavations at Kaštelina. It continued in 2014 within the project IntSYSTEM, Integrated systems of sources, technologies and methods - remote sensing of historical landscape, Intensive programme, field research on the island of Rab, funded by the European Commission. Smaller funds have been allocated by the University of Zagreb within the projects: The transformation of the historical landscape of the island of Rab in 2014, and Transformation of the historical landscape of the Quarnero islands in 2015 and 2016. The field survey of the island and the excavations in Banjol are now part of the project: Croatian medieval heritage in European context: mobility of artists and transfer of forms, functions and ideas (CROMART), funded by the Croatian Science Foundation, and are also supported by the Croatian Ministry of culture. The Italian mission has been funded by the University of Padova (PRAT Project on Paesaggi, Architetture e identità locali nel Medioevo: catalogazione e analisi archeologica) and co-funded in 2016 by the Ministero degli Affari Esteri and the Scuola di Specializzazione in Beni Archeologici.

${ }^{2}$ M. JURKOVIĆ, G.P. BROGIOLO, T. TURKOVIĆ, A. CHAVARRÍA ARNAU, I. MARIĆ, Kaštelina na otoku Rabu. Od rimske vile do ranobizantske utvrde, in J. Andrić, R. Lončarić (eds.), Rapski Zbornik 2, Rab, 2012, pp. 1-13; M. JURKOVIĆ, G.P. BROGIOLO, J. ARCE MARTINEZ, I. MARIĆ, A. CHAVARRÍA ARNAU, La villa Romana di Kastelina (isola di Rab). Indagini Archeologiche (2005-2007), in S. Collodo, G. L. Fontana (eds.), Eredità Culturali dell'Adriatico: Archeologia, storia, lingua e letteratura, Roma, 2008, pp. 99-109

${ }^{3}$ M. JURKOVIĆ, T. TURKOVIĆ, Utvrda sv. Kuzme i Damjana u Barbatu na otoku Rabu, in J. Andrić, R. Lončarić (eds.), Rapski Zbornik 2, Rab, 2012 , pp. 15-36. ${ }^{4}$ G.P. BROGIOLO, M. NEBBIA, F. BENETTI, Ricerche sul paesaggio dell'isola di Arbe, in G. Cuscito (ed.), Le modificazioni del paesaggio nell'altoadriatico tra pre-protostoria e altomedioevo, Antichità Altoadriatiche LXXVI, Trieste, 2014, pp. 217-228.

${ }^{5}$ The excavation comprises the parcel $n^{\circ} 1 / 1$ of the modern cadastre.
} 


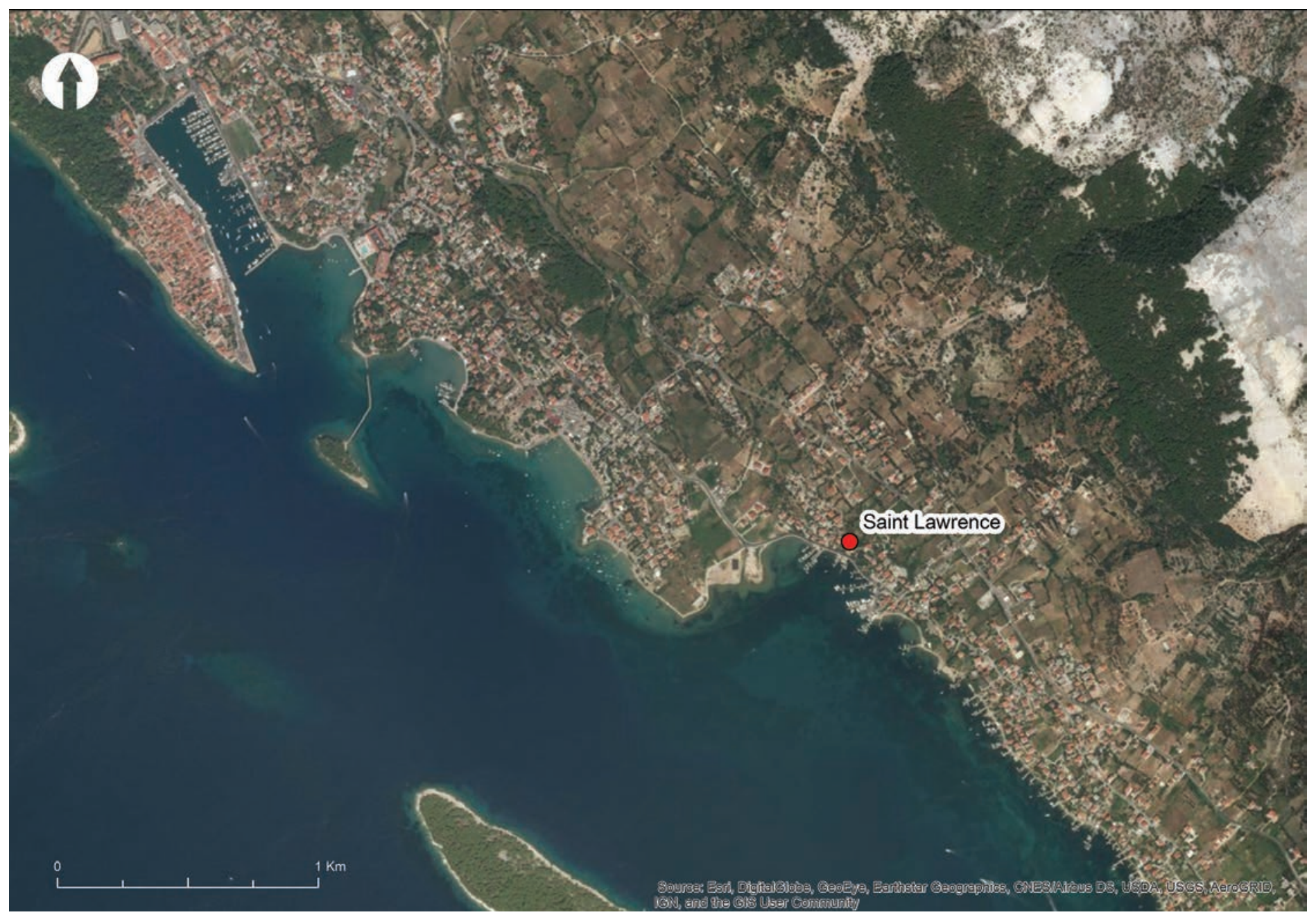

Fig. 2. Location of the site.

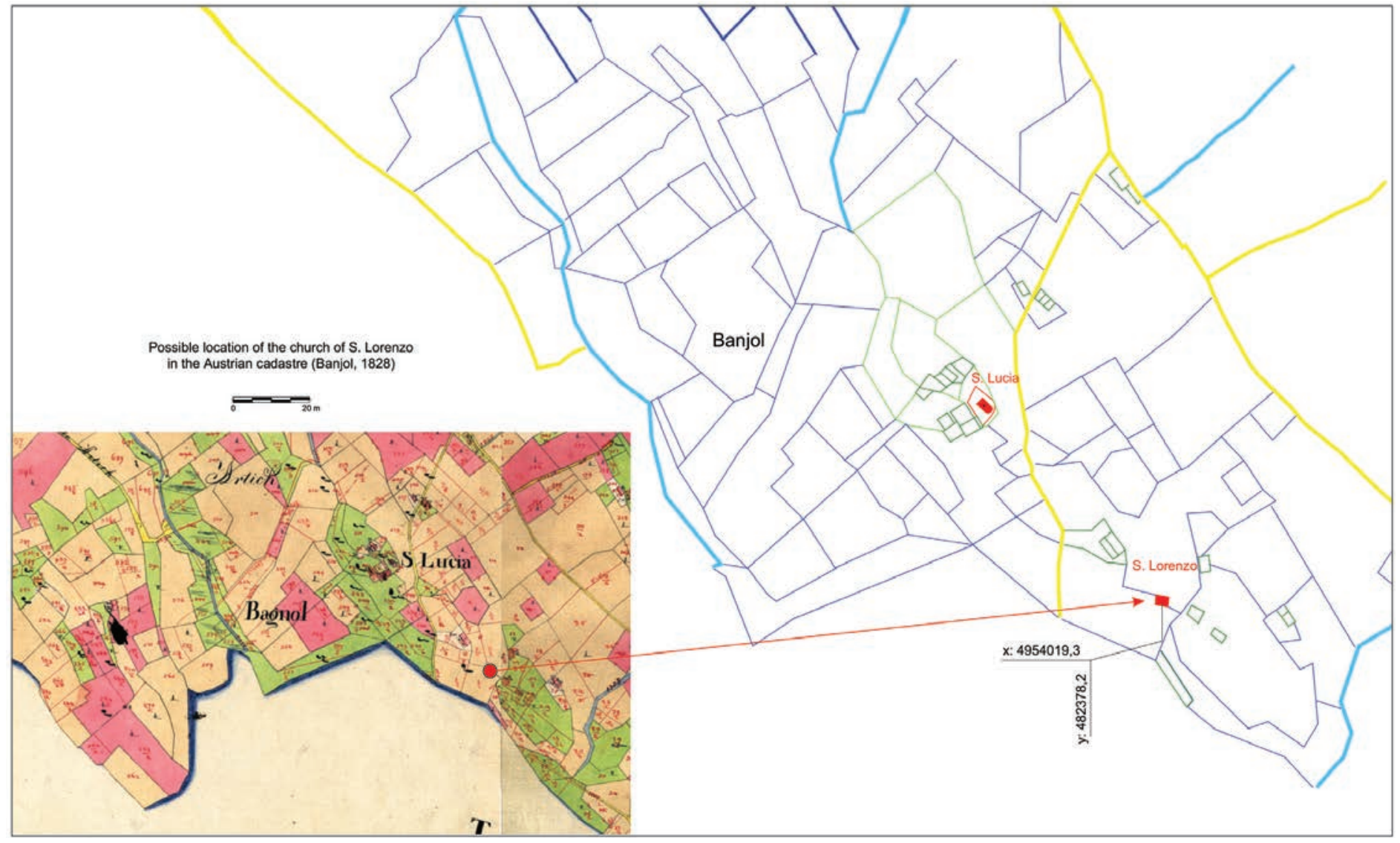

Fig. 3. Drawing of the surroundings of Saint Lawrence based on the Austrian cadastre from 1828. 


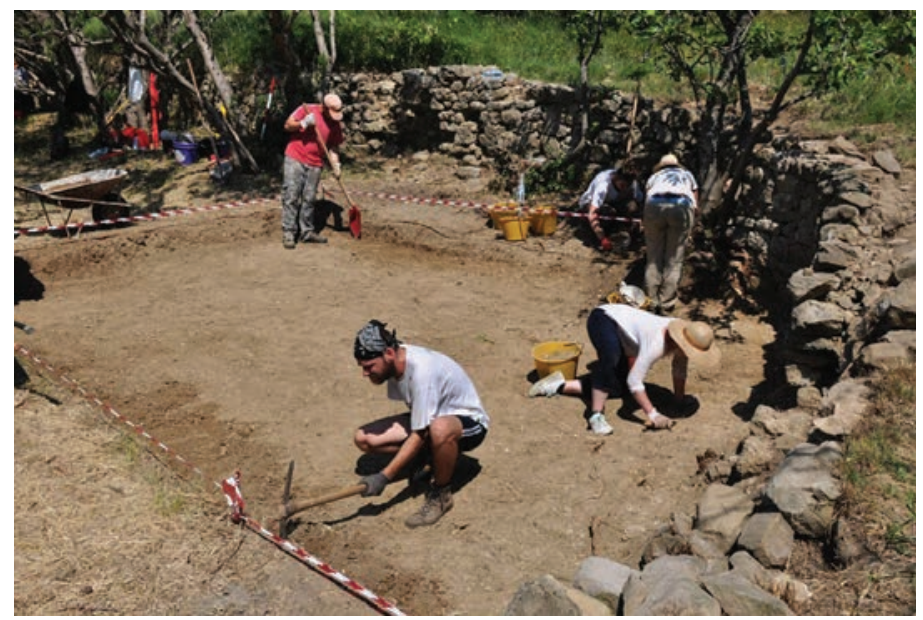

Fig. 4. General view of the excavated area with northern wall of the church in the background (photo:F. Giacomello).

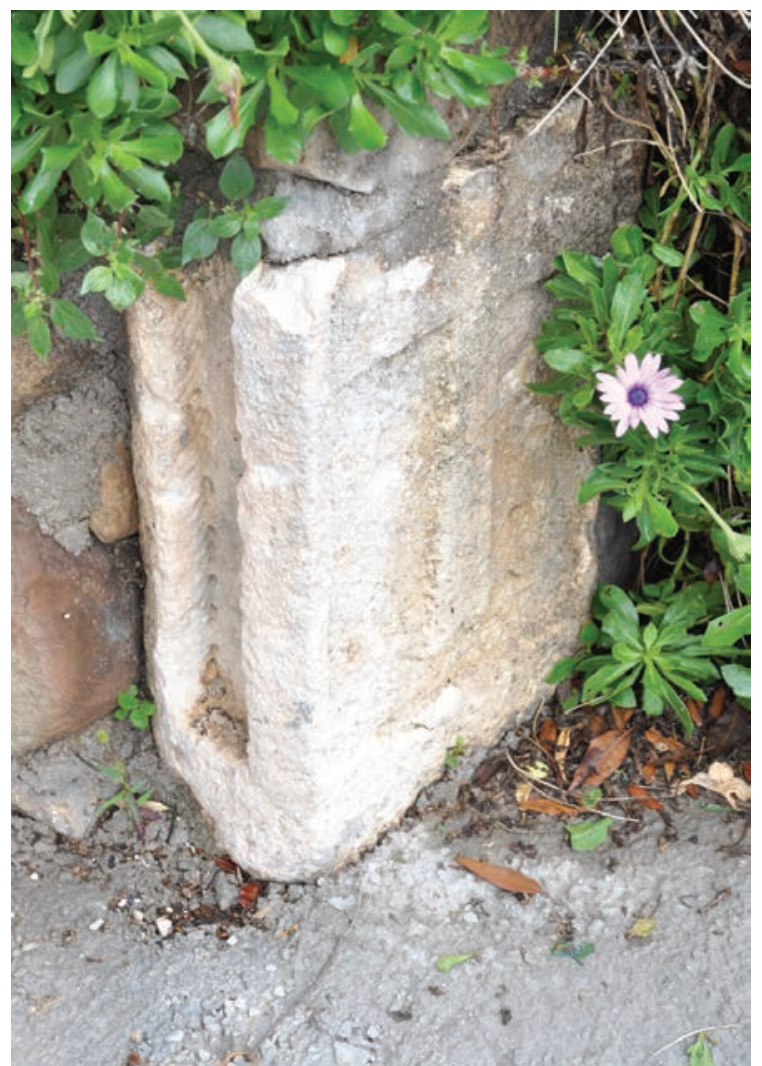

Fig. 6. Sculpture in the garden of a modern house close to the site (photo: F. Giacomello).

ruined walls, preserved to about $1.5 \mathrm{~m}$ in height and reused as the property boundary (fig. 4-5). These should probably be interpreted as the northern and eastern walls of a church;

(c) a large cultivated field in the northern area;

(d) to the east, a modern house has been constructed on the top of a small hill. Several fragments of liturgical furnishings dating to the $6^{\text {th }}$ century have been identified in the garden of this house (fig. 6).

Other than the place-name, the form of the boundary limits and the fragments of sculpture found around the site, as well as oral testimonies referring to old finds of bones and graves attest to the presence of a church in this area.

Several test trenches carried out in the field have documented two different overlapping churches: the first related to a large rectangular building probably dating to the $6^{\text {th }}$

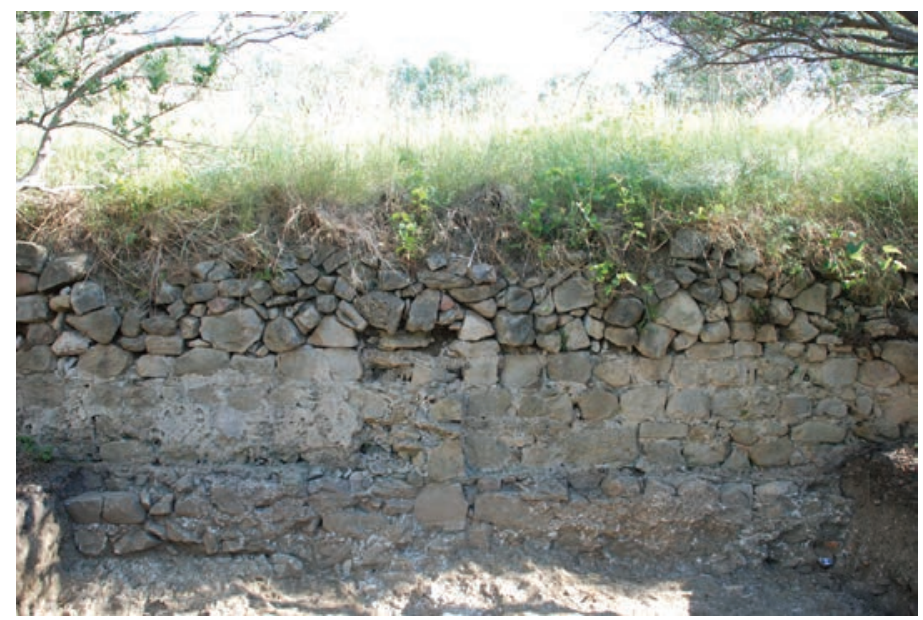

Fig. 5. Northern wall of the church during excavation (photo: F. Giacomello).

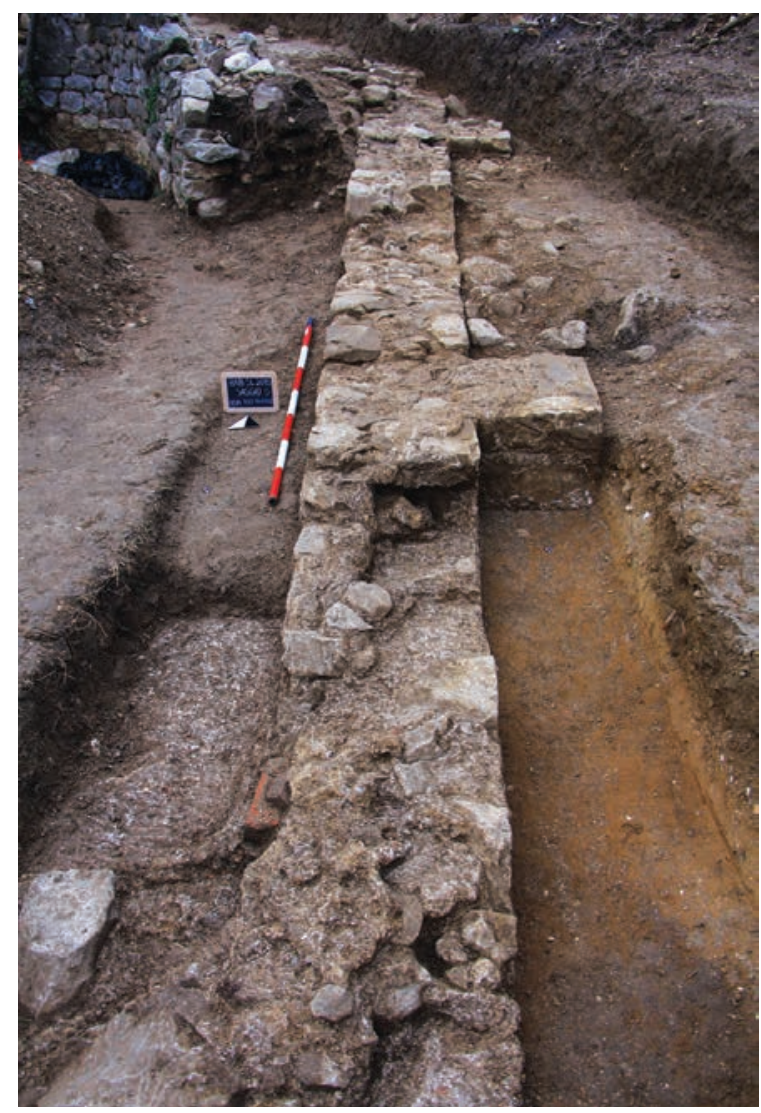

Fig. 8. Eastern wall of the first church (photo: F. Giacomello).

century and a second smaller church with a semicircular apse (of a yet undetermined date).

\section{SEQUENCE AND DATING}

Period 1

The oldest structures brought to light during the first two excavation campaigns are the perimeter walls of the church of Saint Lawrence; it has a rectangular plan of approximately $33 \times 14 \mathrm{~m}$ (fig. 7a, b), including a vestibule on the west. The eastern wall, continuing to the south for at least $0.80 \mathrm{~m}$ outside the church perimeter, suggests the existence of an annex, as in other Late Antique churches.

The walls, $0.65 \mathrm{~m}$ thick, are built with stones of local stone linked by excellent mortar. On the outer faces they are reinforced by pilaster strips ( $\mathrm{m} 0.65 \times 0.45)$, large enough to function as buttresses (fig. 8). Being built on a slight slope, 

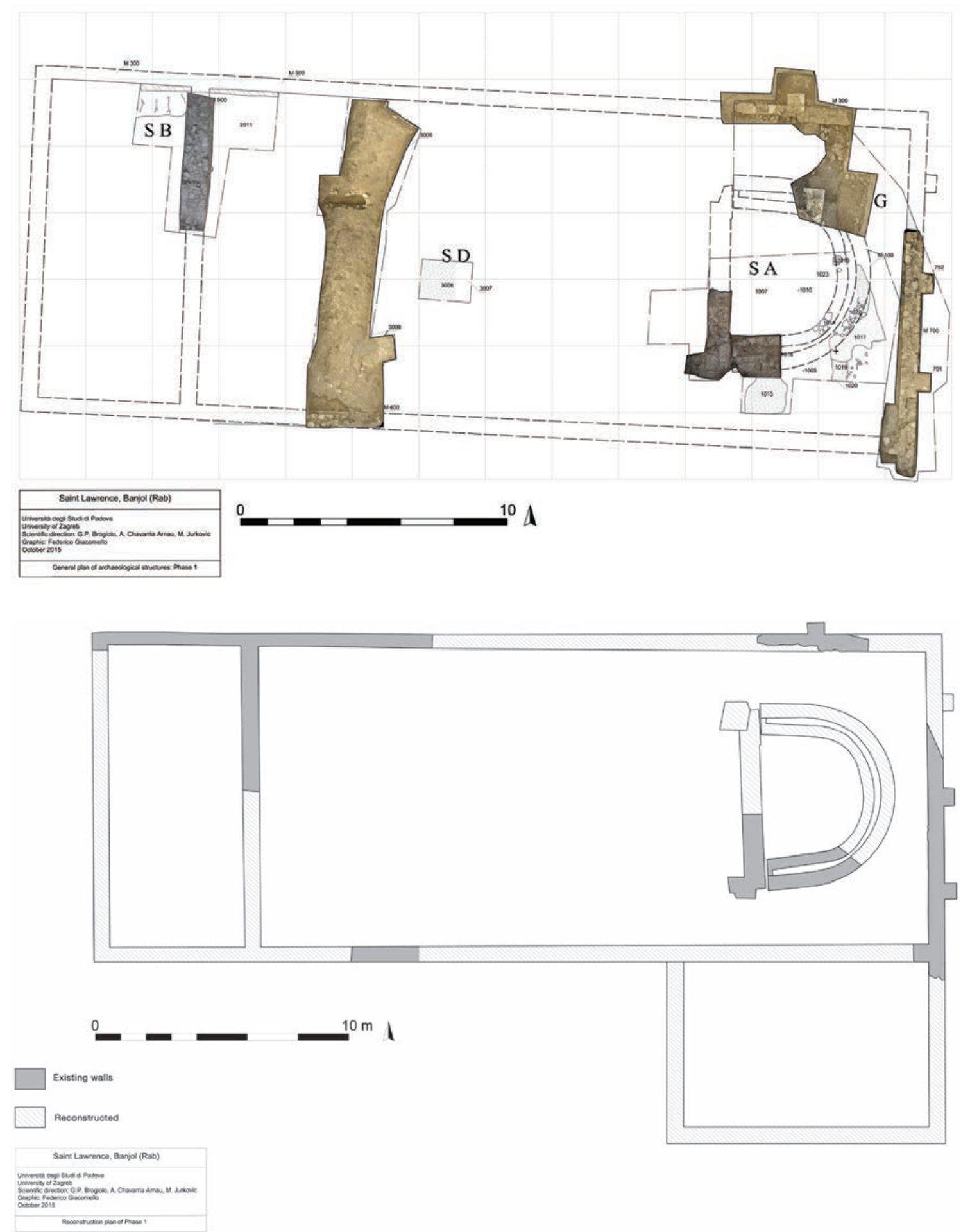

Fig. 7. First church: excavated structures (a) and proposal of layout (b) (after research team).

declining from north to south, towards the seashore, the north wall was built at the level of -0.25 and the south at $-1.15 \mathrm{~m}$ in relation to the modern terrain.

The organisation of the presbytery is much more complex then the simple rectangular layout of the church. It has a free standing subsellium (synthronon), closed by a semicircular wall structure (ca. $6 \mathrm{~m}$ in diameter); its elevation cannot be deduced at this moment - it might have had the form of an apse, or just a simple back of reduced height (fig. 9). This type of free-standing synthronon, isolated at a distance from the eastern wall of the church, is very characteristic for the region of the Eastern Alps and North Adriatic in the $5^{\text {th }}$ century, ${ }^{6}$ sometimes called the Noricum type. The nearest examples can be seen in the cathedrals of Poreč and Pula, or in Nesactium in southern Istria. Two circular imprints in front of the synthronon suggest a complex visualisation of the presbytery. A large capital found as spolia in the wall of the second church (fig. 10) could be connected with those imprints, suggesting a triumphal arch in front of the synthronon. Such a possibility, even if it is too early for conclusions, can be supported by a similar construction on the neighbouring island of Krk. The reconstruction of the presbytery of the large church in Mirine near Omišalj (roman Fulfinum) is very similar to our case: a free standing synthronon, backed

${ }^{6}$ P. CHEVALIER, Les installations liturgiques des églises d'Istrie du Ve au VIIe siècle, Hortus Artium Medievalium 5, Zagreb - Motovun, 1999 , p. 105. 


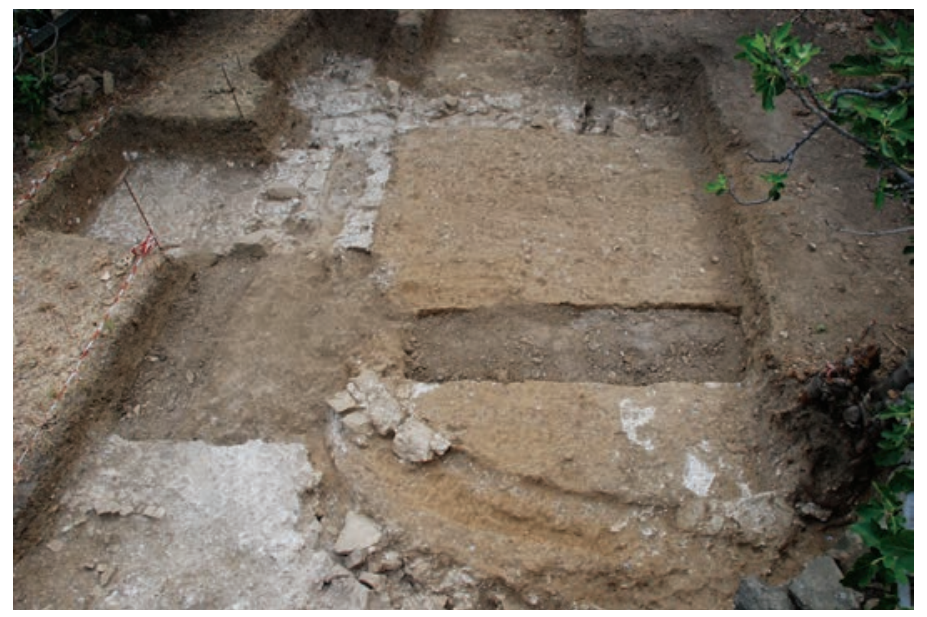

Fig. 9. Presbitery during excavation (photo: F. Giacomello).

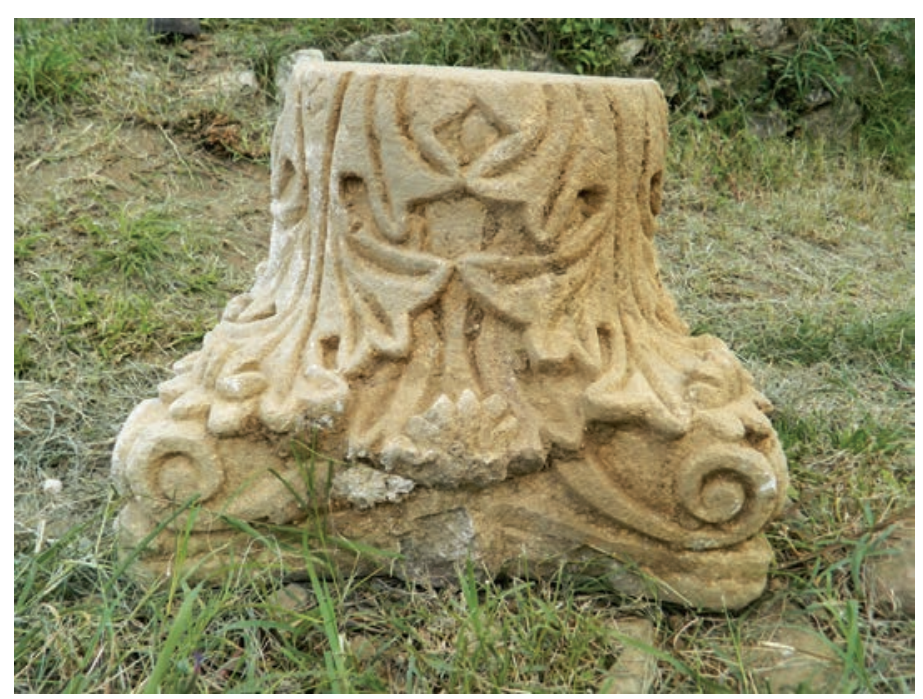

Fig. 11. Capital, $6^{\text {th }}$ c. (photo: F. Giacomello).

by a semicircular apsidal wall in front of which two columns form a triumphal arch. ${ }^{7}$ As for the dating of the capital, the way of rendering the Corinthian leaves is typical for the $6^{\text {th }}$ century (fig. 11).

The free standing synthronon defines towards west an area $(25 \mathrm{~m} 2)$ identified as the liturgical podium or bema where the altar would have been placed. There are no traces of liturgical installations, but fragments of liturgical furnishings found in neighbouring houses suggest a very rich altar screen. A few altar screen colonettes and a capital have been noticed till now, the owners saying that they had all been found around the church. They are carved in marble of eastern origin. The Corinthian capital, pretty worn out, is decorated in the way typical for the first half of the $6^{\text {th }}$ century (fig. 12). At this point of research we can imagine a rich altar screen imported from Constantinopolitan workshops around the mid $6^{\text {th }}$ century.

All test trenches have revealed the presence of an opus signinum floor at a depth of o.60-0.70 $\mathrm{m}$, with a consistent preparation of mortar on a layer of pebbles. The same kind of floor has also been found east of the apsidal / back wall.

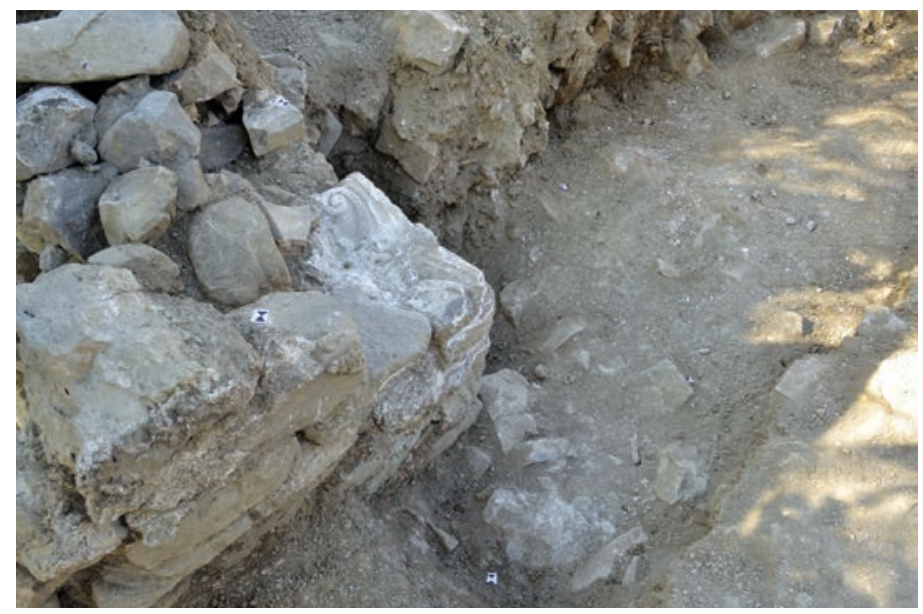

Fig. 10. Capital reused in the structures belonging to the second church (photo: F. Giacomello).

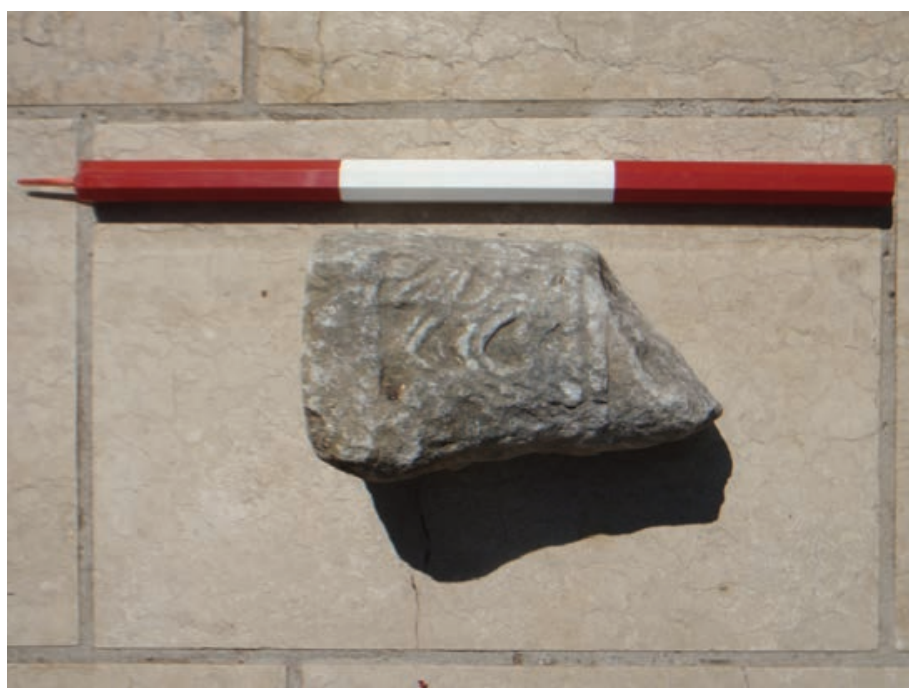

Fig. 12. Altar screen capital, $6^{\text {th }} c$., reused on a terrace of a nearby house (photo: Ivor Kranjec).

\section{Period 2}

At a certain point, the church was completely demolished. Inside its presbytery a new smaller building measuring about $6 \times 13 \mathrm{~m}$ (fig. 13) was constructed. During the first two campaigns the northern wall and a small apse were recognized and excavated. Those walls partly repose on, partly cut the signinum floor of the first church. In a test trench, $9.5 \mathrm{~m}$ from the podium (Trench/Saggio D), a level (ca. $15 \mathrm{~cm}$ ) of stones bound by weak mortar was identified. We interpreted it as the preparation of the floor of the second church. The floor was located at $0.50 \mathrm{~m}$. We do not have any element for dating this phase yet. ${ }^{8}$

Probably belonging to this period (as it cuts the floor of the first church) is a burial of a 40-50-year-old woman in a simple grave cut (fig. 14).

\section{Period 3}

At some later point in time the northern and southern walls of the first church were partly reused and reconstruc-

\footnotetext{
7 N. NOVAK, Le chœur de l'église paléochrétienne de Mirine près d'Omišalj sur l'île de Krk, Hortus Artium Medievalium 5, Zagreb - Motovun, 1999, pp. 119-131. ${ }^{8}$ Similar cases of rebuilding a smaller church in the presbytery area of the former, bigger one are not unusual in Dalmatia during the early middle Ages. For the $11^{\text {th }}$ c. see for example: I. FISKOVIĆ, Apport des reconstructions d'églises de l'antiquité tardive dans la formation du premier art roman sur le littoral croate, Hortus Artium Medievalium 1, Zagreb - Motovun, 1995, pp. 14-27.
} 

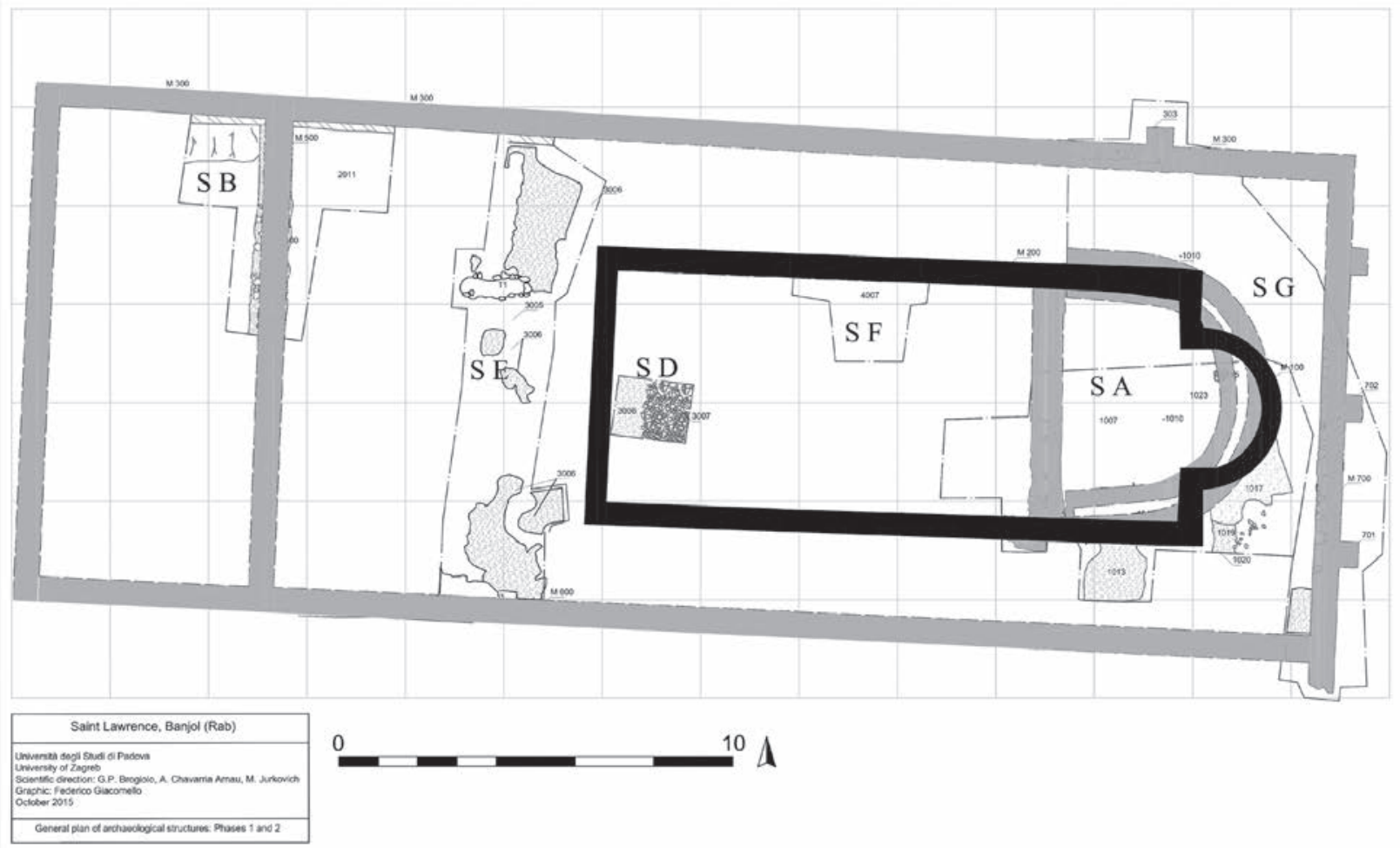

Fig. 13. Plan of the second church (after research team).

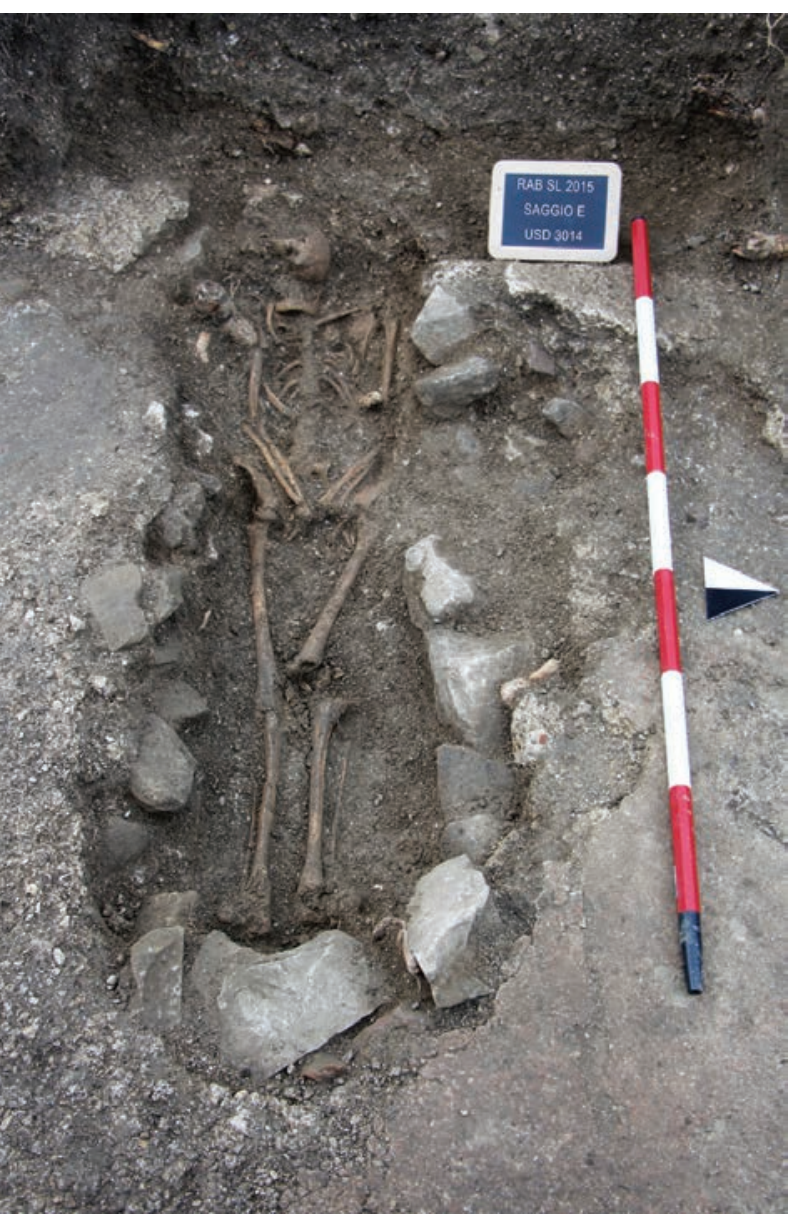

Fig. 14. Burial located near the western wall of the second church (photo: F. Giacomello).

ted with drystone walls to make part of the agricultural terracing walls. Skeletal remains of several individuals were found, buried against the apse of the smaller church, on its northern side, in what seems to be one, or possibly even two successive pits (fig. 15). The exact date of these secondary

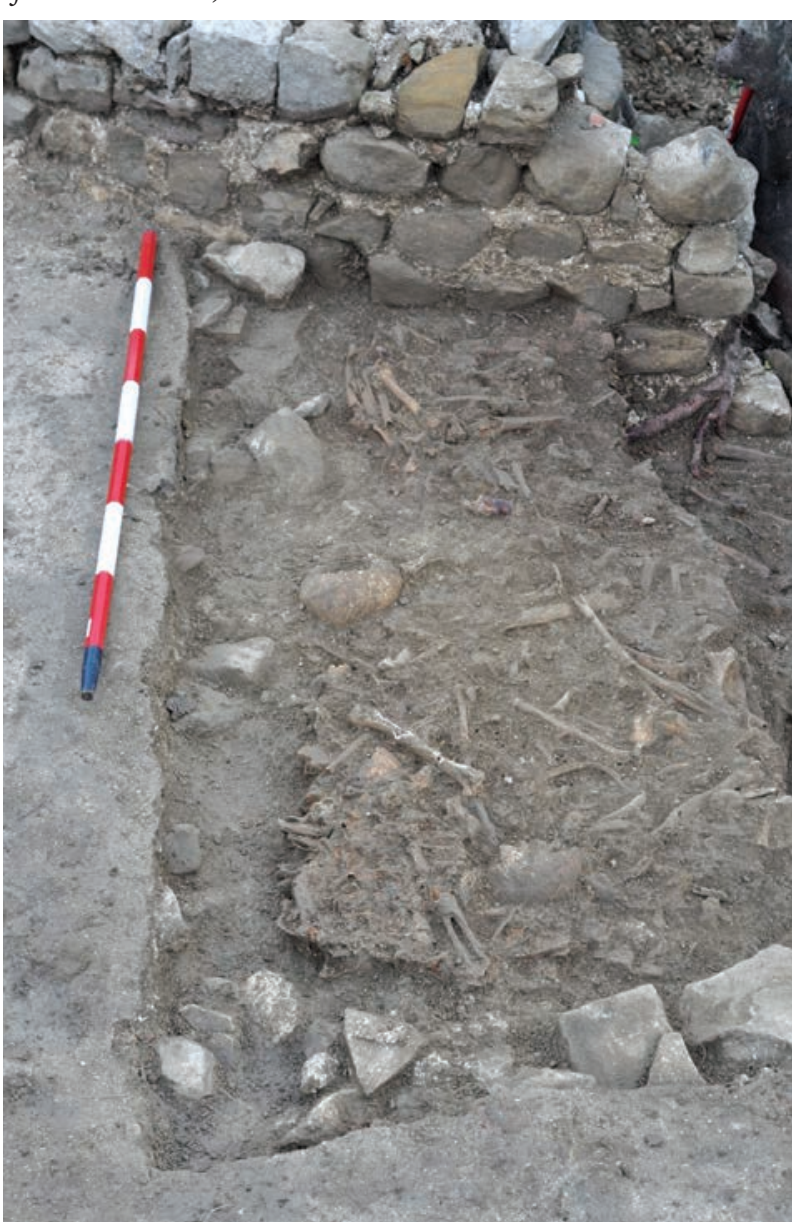

Fig. 15. Ossuarium located against the apse of the second church (photo: F. Giacomello).

burials is unknown. However, the bones were buried quite above the presumed original level of the walking surface around the smaller church, thus obviously post-dating it significantly. Also, local inhabitants stated that their recent ancestors used to come upon graves while cultivating land 

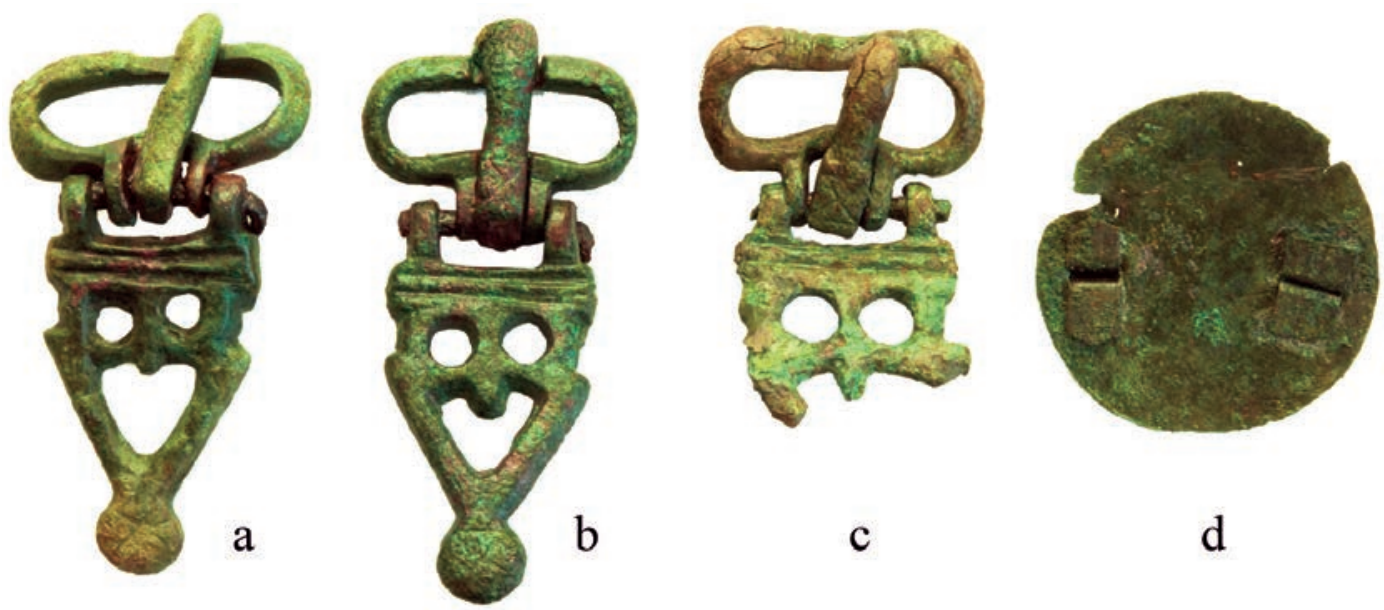

c

d
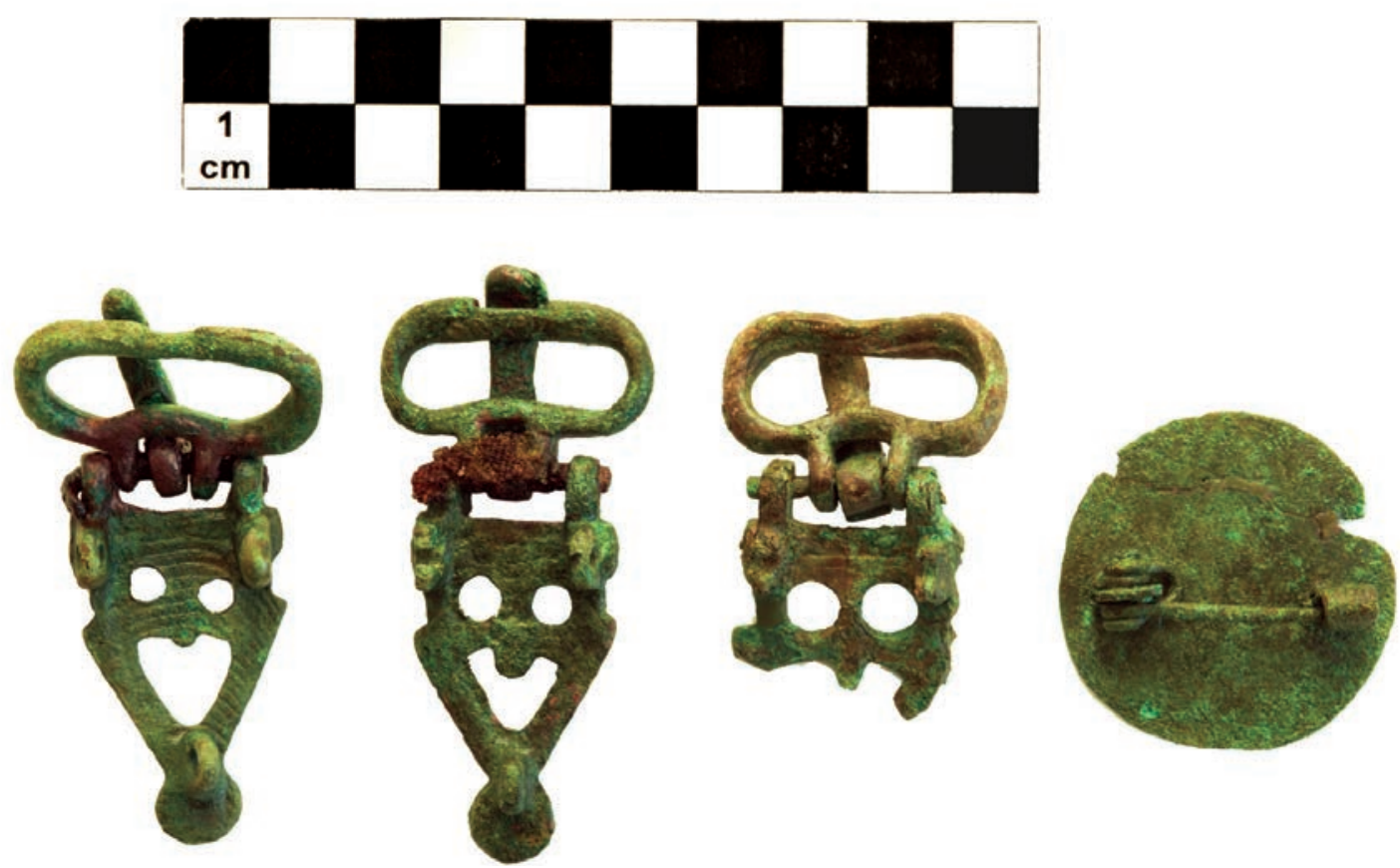

Fig. 16. Belt buckles and brooch from the ossuarium (photo: G. Bilogrivić).

surrounding the site, so it can't be excluded that these bones might have been transferred from nearby graves only at some point(s) in the late $19^{\text {th }}$ or early $20^{\text {th }}$ century. Although the original context has been destroyed, at least some of those initial graves can be dated by several finds discovered among the bones. First of all, three copper-alloy belt buckles. One complete example has incised decoration ("X"-mark?) on its disc-shaped ending and a small " $\mathrm{X}$ " on the base of the tongue (fig. 16a). 9 The other one has similar incised "X"-marks in the same places, as well as preserved traces of fabric on the back side of the hinges (fig. 16b). ${ }^{10}$ Of the third buckle only its loop, tongue and parts of openwork plate are preserved."
The loop has two groups of parallel ornamental grooves, and an " $\mathrm{X}$ " is also incised on the rectangular base of the tongue (fig. 16c). Both complete buckles have iron pins which are somewhat disproportionately protruding and bent on one side, while the fragmentary buckle has a copper-alloy pin. This might indicate that the first two had been repaired at some point during their use. In any case, all three buckles can be determined as the Corinth type, which is usually dated to the second half of the $7^{\text {th }}$ century. ${ }^{12}$ They are most often associated with military or administration dignitaries, ${ }^{13} \mathrm{al}-$ though several examples are also known from female graves. ${ }^{14}$ Buckles of the Corinth type are not a rare find on the eastern

\footnotetext{
${ }_{9}$ L. $6.4 \mathrm{~cm}$; plate w. $2.3 \mathrm{~cm}$; attachment loop h. $0.6 \mathrm{~cm}$. There are also shallow radial grooves visible on the back.

${ }^{10}$ L. $6.9 \mathrm{~cm}$; plate w. $2.3 \mathrm{~cm}$; attachment loop h. $0.6 \mathrm{~cm}$.

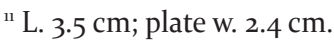

${ }^{12}$ For a general overview of the type (therein determined as E6), with earliear literature, new findings and dating see M. SHULZE-DÖRRLAMM, Byzantinische Gürtelschnallen und Gürtelbeschläge im Römisch-Germanischen Zentralmuseum. Teil II. Die Schnallen mit Scharnierbeschläg und die Schnallen mit angegossenem Riemendurchzug des 7. bis 10. Jahrhunderts, Mainz, 2009, pp. 19-26, 354. Cf. also E. RIEMER, Romanische Grabfunde des 5.-8. Jahrhunderts in Italien, Rahden/Westf., 2000, pp. 153-157; E. NALLBANI, Precisions sur un type de ceinture byzantine: la plaque-boucle du type Corinthe au haut Moyen $\hat{A}$ ge, in F. Baratte et al. (eds.), Mélanges Jean-Pierre Sodini, Paris, 2005, pp. 655-672. Nallbani proposes a slightly wider dating period, extending to the early $8^{\text {th }}$ century.

${ }^{13}$ Cf. N. POULOU-PAPADIMITRIOU, Les plaques-boucles byzantines de l'île de Crète (fin VII -IX $X^{e}$ siècle), in F. Baratte et al. (eds.), Mélanges Jean-Pierre Sodini, Paris, 2005, p. 692.

${ }^{14}$ SHULZE-DÖRRLAMM, op. cit. (n. 12), p. 25; F. CURTA, Burial in Early Medieval Greece: On Ethnicity in Byzantine Archaeology, in B. Borisov (ed.), Prof. $d$-r Boris Borisov učenici i prijateli. Studia in honorem professoris Borisi Borisov, Veliko Tărnovo, 2016, pp. 424, 426.
} 
Adriatic coast and its hinterland, being especially abundant in its southern part (Albania, Montenegro). ${ }^{15}$ More than 10 finds are also known from Croatia - four from its southern islands (Hvar and Majsan) and at least seven from Istria. ${ }^{16}$ The finds from Banjol are the first of this type from northern Adriatic islands and also represent the largest number of Corinth type buckles from any single site in Croatia.

A disc brooch of thin copper-alloy sheet was also discovered among the bones (fig. 16d). It's surface is smooth, only with protruding endings of the pin base and catch-plate folded and hammered out. The pin is from the same material and has an integral coiled spring. ${ }^{17}$ Direct analogues can be found on sites from Albania, e.g. in Krujë and Lezhë. ${ }^{18}$ The brooch from grave 7 in Lezhë is especially indicative, since it was accompanied with, among other grave goods, a belt buckle of the Boly-Želovce type, dated firmly to the $7^{\text {th }}$ century, often to it's middle and the second half.19 The same dating can therefore be established for the Banjol brooch. Furthermore, three glass paste beads, likewise discovered among the bones, can also be dated roughly to the same period. It is thus safe to conclude that a cemetery existed around the first church in the $7^{\text {th }}$ century. So far no earlier grave goods have been found, but future excavations will hopefully answer the question whether it's beginnings were closer to the building of the church.

\section{DISCUSSION OF THE RESULTS}

Although the presence of important Late Antique and early Medieval churches on the island of Rab, in the city as well as in the countryside, is well known, the discovery of a new, until now unknown church is of critical importance for the reconstruction of the ecclesiastical history of the island and for better understanding of its population and economic patterns. That this research has revealed an important building is demonstrated by the following facts: 1. its large dimensions ( $14 \times 33 \mathrm{~m})$, which are only surpassed by those of the cathedral; 2 . the complex liturgical arrangements present in the eastern presbyterial area, comparable to urban episcopal complexes in the Adriatic (Poreč, Pula) and some suburban martyrial churches in other areas (northern Italy for example: Saint Peter in Mavinas, Saint Lawrence di Aosta) ${ }^{20}$. These kinds of structures must be linked to founders of high rank, generally the bishops but also possibly high status and wealthy Christian property owners; 3. rich sculptural decoration well dated to the first half of the $6^{\text {th }}$ century; 4 . the existence of a privileged cemetery with grave goods, the study of which can assist our interpretation of its function and the founder's milieu.

Future excavations will allow us to identify the entire perimeter of the two churches, other architectural and liturgical characteristics and the relationship with the surrounding settlement. It will also be interesting to analyse its relationship with the other churches of Rab and its significance to the city and the territory in a period (Late Antiquity) in which the society and economy of this island must have been particularly significant, judging by the rich architectural heritage that has been preserved up to the present day.

\footnotetext{
${ }^{15}$ See the distribution map in SHULZE-DÖRRLAMM, op. cit. (n. 12), p. 23, fig. 7. Cf. also M. MILINKOVIĆ, Einige Bemerkungen zu spätromanischen Funden in Süddalmatien und Montenegro, in C. Dobiat (ed.), Reliquiae gentium. Festschrift für Horst Wolfgang Böhme zum 65. Geburtstag. Teil I, Rahden/Westf., 2005, passim.

${ }^{16}$ Cf. Z. VINSKI, Kasnoantički starosjedioci u salonitanskoj regiji prema arheološkoj ostavštini predslavenskog supstrata, in Vjesnik za arheologiju i historiju dalmatinsku 69, Split, 1967 [1974], pp. 25-27; T. FABIJANIĆ, Pojasne kopče i pređice druge polovice 5. do 7. st. na području rimske provincije Dalmacije, unpublished MSc thesis, University of Zagreb, Zagreb, 2004, pp. 85-87.

${ }^{17}$ Diameter is $3.8 \mathrm{~cm}$, and pin $1.3 .2 \mathrm{~cm}$.

${ }^{18}$ Cf. S. ANAMALI, H. SPAHIU, Varreza arbërore e Krujës, in Iliria 9-10, Tiranë, 1979-198o, pp. 63, 66, T. VIII/1; F. PRENDI, Një varrezë e kulturës arbërore në Lezhë, in Iliria 9-10, Tiranë, 1979-1980, pp. 127, 133, T. III, XX/10. The Albanian examples are somewhat larger, though, at around 5,5 and 6,4 cm in diameter, respectively. The cited authors also express a possibility that the brooches originally had additional decoration made from some kind of organic or otherwise perishable material. No such traces were found on the Banjol example. For a detailed overview of various types of Byzantine disc brooches in Late Antiquity and the Early Middle Ages see E. RIEMER, Byzantinische und romanisch-mediterrane Fibeln in der Forschung, in F. Daim, J. Drauschke (eds.), Byzanz - das Römerreich im Mittelalter. Teil 1. Welt der Ideen, Welt der Dinge, Mainz, 2010, pp. 303-310.

${ }_{19}$ PRENDI, op. cit. (n. 18), pp. 136-137, T. XXI/1. For the Boly-Želovce type buckles see U. IBLER, Pannonische Gürtelschnallen des späten 6. und 7. Jahrhunderts, in Arheološki vestnik 43, Ljubljana, 1992, pp. 138-140; POULOU-PAPADIMITRIOU, op. cit. (n. 13), pp. 695-696; SHULZE-DÖRRLAMM, op. cit. (n. 12), pp. 77, 79. Also V. VARSIK, Byzantinische Gürtelschnallen im mittleren und unteren Donauraum im 6. und 7. Jahrhundert, in Slovenská archeológia XL/1, Bratislava, 1992, pp. 85-89, T. V/5-6, where these buckles are considered as a subgroup of the Keszthely-Pécs type, but dated likewise to the $7^{\text {th }}$ century. The Keszthely-Pécs type was defined by VINSKI, op. cit. (n. 16), pp. 33-37.

${ }^{20}$ See for a synthesis G. CUSCITO, L'arredo liturgico nelle basiliche paleocristiane della "Venetia" orientale, Hortus Artium Medievalium 5, Zagreb - Motovun, 1999, pp. 87-104.
} 